\title{
Reshaping urban space through studentification in two South African urban centres
}

\author{
Ronnie Donaldson \\ Julian Benn \\ Malene Campbell \\ Annelie de Jager
}

Ronnie Donaldson, Stellenbosch University, Department of Geography and Environmental Studies, South Africa (rdonaldson@sun.ac.za)

Julian Benn, Stellenbosch University, Department of Geography and Environmental Studies, South Africa

Malene Campbell, University of the Free State, Department of Town and Regional Planning, Bloemfontein, South Africa (campbemm@ufs.ac.za)

Annelie de Jager, University of the Free State, Department of Town and Regional Planning, Bloemfontein, South Africa

\begin{abstract}
Accommodation shortages on campus force students to find accommodation in the private sector. These shortages result in single family residents increasingly being targeted for redevelopment into student housing. Studentification is a process where the original residents in the vicinity of tertiary institutions are gradually displaced due to an in-migration of students causing spatial dysfunctionality where, eventually, only the needs of a student subculture are catered for. The purpose of this paper is to provide insights into the reshaping of urban space due to studentification in the two South African cities of Bloemfontein and Stellenbosch. Empirical data on key aspects of studentification was obtained from two questionnaire surveys among permanent residents, as well as students, in both cities. The paper proposes that the main role-players, such as universities and local municipalities, should ideally all form part of planning strategies for student housing.
\end{abstract}

Keywords: studentification, Stellenbosch, Bloemfontein, urban restructuring, neighbourhood quality

\section{Introduction}

At a global scale the growth in university student population is outgrowing the supply of accommodation by the higher education institutions (Slater, Curran \& Lees 2009; Duke Williams 2009). Such accommodation shortages necessitate students to find alternative accommodation in the private sector. In turn, the private sector has identified student accommodation as a niche market. To cater for these urban demands - planning policy more often than not - is formulated to change the zoning from single residential to general residential, resulting in social protest by residents against the anticipated fear of their suburb being invaded by student accommodation. Depending on the location in relation to the universities, in many cases single residential properties are increasingly targeted for redevelopment into medium and high density housing complexes. Studentification is a process where students start inhabiting certain parts of a suburb or town in the vicinity of a tertiary institution and the original residents are gradually displaced due to this in-migration. The spatial consequences of studentification are immense and include an array of economic, social, physical and cultural impacts (Allison, 2006; Chatterton, 2000). In some cases such invasion is referred to as "student ghettos" (Leavey, 2004: 22). Studentification is defined as a 
form of urbanism that results from the concentration of residential areas by higher education students (Sabri \& Ludin, 2009). The progression of studentification eventually results in a complete spatial restructuring and re-organisation of a particular area in a city. Studentification of suburbs causes spatial dysfunctionality where, eventually, only the needs of a student subculture are catered for. Studentification as urban spatial process, therefore, has various social, cultural, physical, economic and spatial effects (Hubbard, 2006; Munro, Turok \& Livingston, 2009; Smith \& Holt, 2007).

South Africa began restructuring its higher education system in 2000 to widen access to tertiary education and reset the priorities of the old apartheid-based system. Smaller universities and technikons (polytechnics) were incorporated into larger institutions to form comprehensive universities. Today there are 23 universities in the country and another two are in the process of being built in Kimberley and Nelspruit. Surprisingly, with the exception of the study of Potgieter (2005) there has been no academic research into the impact of student accommodation on urban space in South African cities. The paper is an attempt to provide insights into the impacts of studentification of urban space in the two South African cities of Bloemfontein and Stellenbosch. The aim of the study is not to compare the two study sites because they are too different in context, scale and size. The same process of studentification in suburbs adjacent the respective university campuses have been observed, but the spatial impacts have had different outcomes whilst the social and cultural aspects are echoed. Findings in the paper are based on empirical data obtained from two questionnaire surveys among permanent residents, as well as students, in both cities. The aim of the surveys was to identify key aspects of the studentification process. In Bloemfontein, 100 randomly sampled student houses were identified for participation in a questionnaire survey. Addresses of student houses in Universitas and Brandwag (two suburbs in Bloemfontein close to the University of the Free State) were identified from the university's student registration list. In addition, eight in-depth interviews with permanent home owners living adjacent student houses were conducted. In Stellenbosch a total of 41 student houses and 40 permanent residents were interviewed. To track the reshaping of the urban fabric in the Stellenbosch suburb of De Weides, mapping the land use changes was done by means of a land use audit form 1999, 2005, 2008, 2010, 2011 and 2012 using GPS plotting, satellite imagery and aerial photographs.

\section{Understanding studentification impacts}

Urban landscapes are continuously changing (Zhang et al., 2012; Stefanovska \& Koželj, 2012). Studentification is not a process that occurs in a vacuum. However, each studentification context in a given city may differ as a result of the contributions of the various roleplayers. Hubbard (2006) identifies six main roleplayers: students, higher education institutions, local authorities, developers (private sector), home-owners and permanent residents. Students have a typical demographic and social characteristic profile. They are predominantly young, come from middle-class backgrounds, have no dependents and have been brought-up relatively well-mannered (Munro, Turok \& Livingston, 2009: 1807). Student accommodation in suburbs/neighbourhoods provides students a way to live an independent lifestyle where they are mostly free from house rules and regulations (Smith \& Holt, 2007: 152; Smith, 2007). Their profile is that of "free and mobile" (Munro, Turok \& Livingston, 2009). In the absence of parents or guardians, students see this freedom as an opportunity to enter the life cycle of adults with no one looking over their shoulders (Smith \& Holt, 2007: 153). Because of demand and supply factors students are flexible tenants and they do not have all the preferences and requirements that a family would have (Rugg, Rhodes \& Jones, 2000). Students are seen as profitable tenants. Additionally, they are, according to Hall (2008), the most exploited housing market, because they pay high rental for poor quality 
accommodation. Students are also temporary residents in an area; hence adjacent studentified suburbs literally become an extension of the university campus (Bowditch, 2001: 14). According to Smith and Holt (2007) student accommodation is a distinct niche market for developers and home-owners (who would mostly target suburb areas adjacent to campuses). However, this leads to a range of socio-spatial and economic impacts.

Social aspects related to studentification refer to the replacement of established residents with those of students. New residents bring new habits, behaviours and social changes. Higher population densities, as a result of over-concentration (illegally) of students in houses, brings about an imbalance in population diversity (Hubbard, 2006: 333) and in the process studentification contributes to destabilising the homogeneity of an area. The geographic concentration of students are at times encouraged by a so-called "pub-culture" present in an area and this serves as a pull factor for them to locate in such an area (Sabri \& Ludin, 2009). With studentification the spatial dimension of an area overwhelmingly becomes dominated by this new sub-culture of students.

Students' presence is also seasonal; thus contributing to a state of discontinuity and the creation of sustainable neighbourhoods (Kenyon, 1997). Student accommodation is prone to become targets for criminals due to houses being unoccupied during recess periods (generally up to a quarter of the year) (Kenyon, 1997: 291). Permanent residents are, therefore, living in fear of their area changing into crime hotspots. As crime is a main push factor to sell one's property, a domino effect takes place with more and more permanent residents putting their properties on the market and developers moving in. However, there are also cases where studentification of an area has indeed contributed to the renewal of decaying areas (Allison, 2006; Curtis, 2005; Harris \& McVaigh, 2002; www.communities.gov.uk, 2008).

Social consequences of studentification will greatly depend on size, intensity and quality of student accommodation and population in a neighbourhood (Macintyre, 2003: 116). Culturally, studentification refers to lifestyle activities and a changing consumer pattern of residents (Griffiths, Bassett \& Smith, 1999; Standing Conference of Principals \& the Local Government Association, 2006; Wynne \& O’Connor, 1998). Retail and service sector practices are becoming more diversified and in some cases the traditional restaurants and bars are replaced by fast food restaurants and outlets as well as theme bars (Wojtas, 2003). The cultural needs and interests of students are thus creating friction between students and permanent residents (Russo, Van den Berg \& Lavanga 2007: 201). Anti-social behaviour of students - in many cases attributed to high consumption of alcohol (Allison, 2006: 88) contributes to an increase in noise levels (Smith \& Holt, 2007). On the contrary, Curtis (2005) believes that students bring local cultural diversity to places with a lively dynamic and according to Midgley (2002) they should also be seen as cultural investors to an area.

Environmental decay is generally associated with studentification of areas in a city. Overpopulation (the increase of residents in a single family housing unit), increase in traffic, insufficient facilities, vandalism, graffiti, gardens that are not maintained, inconsiderate parking and refuse are all common types of environmental factors in such areas (Midgley, 2002; Rugg, Rhodes, \& Jones, 2000: 28; Smith \& Holt, 2007: 145). Russo et al. (2007: 205) argue that students have the power to transform the socio-economic structure of their areas to meet their needs.

Decaying of urban space has a direct influence on the economic value of properties in an area. Economic ramifications of studentification are said to impact supply and demand, house price inflation, conditions of housing structures and a seasonal economic growth (Hall, 2008; Hubbard, 2006; Macintyre, 2003; Russo et al., 2007; Standing Conference of Principals \& the Local Government Association, 2006). Similarly, as is the case in gentrification, the rent-gap theory (Smith, 1987) can be applied to studentification. From a studentification point of view gentrification contributes to the redevelopment of certain areas and this in turn restricts a 
certain income class to afford buying property in these areas (Lees, 2008). Gentrification, caused by studentification, at times contributes to a more affluent student being attracted and eventually pushing up property and rental prices.

A last dimension of studentification, namely spatial, generally refers to a combination of social, cultural, physical and economic dimensions of the process. Studentification has an indirect impact on the control, regulation and planning of the spatial dimension of neighbourhoods. Diverse challenges for spatial planning are posed and it places the sociospatial needs of families and those of students in a direct contest (Albrechts, 2004; Wojtas, 2003). Planning policy, more often than not, is adapted to match the needs of students when single residential units are rezoned to general residential land use. Such zoning changes result in social conflicts because permanent residents opt for neighbourhoods allowing only single residential land use. High density accommodation is, however, not a direct consequence of studentification. It is rather developers that expose the housing shortage for students as an opportunity to create high density accommodation (Rey, 2007).

\section{Case studies}

Stellenbosch is situated 50km from Cape Town in the Western Cape province of South Africa. This historic town is located in the heartland of the Winelands and is South Africa's oldest town established in 1679. In 1990, Stellenbosch University registered 11379 students and the number increased by 237\% to 26964 in 2010 (Benn, 2010). At present there are just over 14000 students in Stellenbosch (the university also has a satellite campus in Saldanha and Cape Town, respectively 200 and 30 kilometres away) and the university houses around 8000 students, leaving over 6000 students having to find alternative accommodation in the private sector. Today, the university is considered as one of the top two research universities in South Africa. Unlike most universities in South Africa, Stellenbosch University is spatially part and parcel of the cityscape. There is free movement between the campus and the city the campus is located in the central business district (CBD). The second case study is in Bloemfontein, the provincial capital of the Free State province and recently proclaimed as one of South Africa's metropolitan municipal areas. The city was established in 1854 and the Grey University College (University of the Free State, as it is known today) was established in 1904 - a direct ramification of Grey College, the high school that was established in 1856 (Groenewald, 1989:30). Unlike Stellenbosch, the campus is completely fenced off from the rest of the city, although it is relatively closely located to the CBD. With currently over \pm 30 000 students on three campuses, two in Bloemfontein and one in QwaQwa, $345 \mathrm{~km}$ north east of Bloemfontein, the university can only cater for just over 5000 beds; 3970 in Bloemfontein and 1052 on the Qwaqwa campus. If $17 \%$ of students leave campus it leaves just less than 25 000 to students to find off-campus accommodation. Both case study universities are former Afrikaans-only speaking universities where the policy of apartheid, in terms of university education, benefited white Afrikaans speaking South Africans. Both urban contexts of the origins of the cities are strongly based on Afrikaner history. Today, both universities are still struggling to rid the effect of Apartheid education on the psyche of the institutions where issues of racial and language integration have become new playgrounds of struggle for equity and diversity.

\section{Stellenbosch}

Students that cannot find accommodation on campus generally prefer to be located as close to the institution as possible (Curtis, 2005). They will, therefore, as far as possible move into those suburbs located adjacent the campus and the spatial distribution of them in urban spaces will determine the impact it may have on the surrounding area. Figure 1 shows the spatial distribution of students living in Stellenbosch in private accommodation (not all are 
houses). The highest concentration is observed in the central part of the city where the university campus is located (mostly in high density flats), but a significant number of students are living in the area north of the core - suburbs such as La Colline, De Weides and Simonswyk - all as a result of rezoning from single residential to student housing (multiple accommodation housing where the owner does not live on the property; only students live there). Unlike Bloemfontein, the Stellenbosch zoning scheme makes provision for such a category.

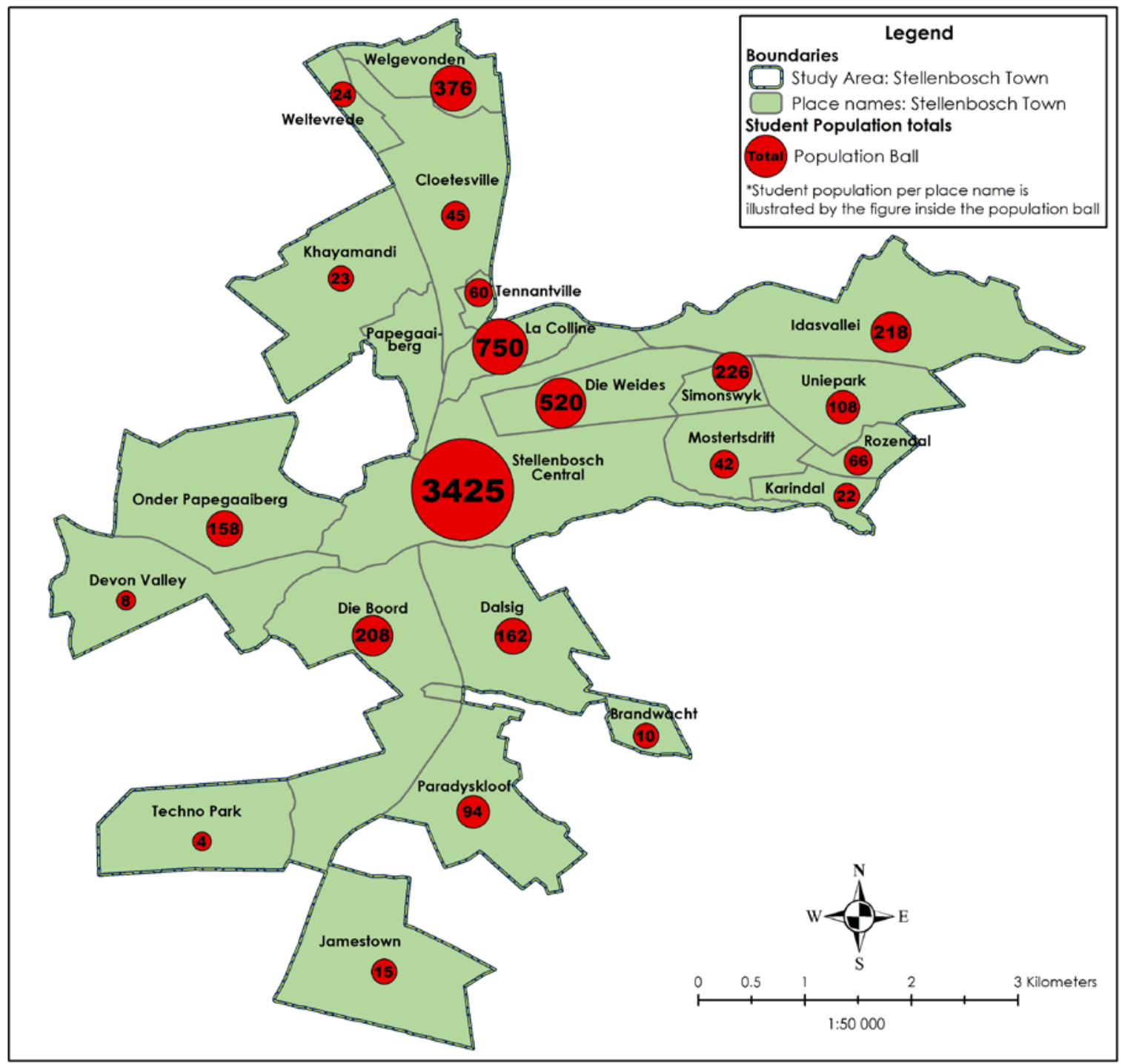

Figure 1: Spatial location of students' place of accommodation (2010) 


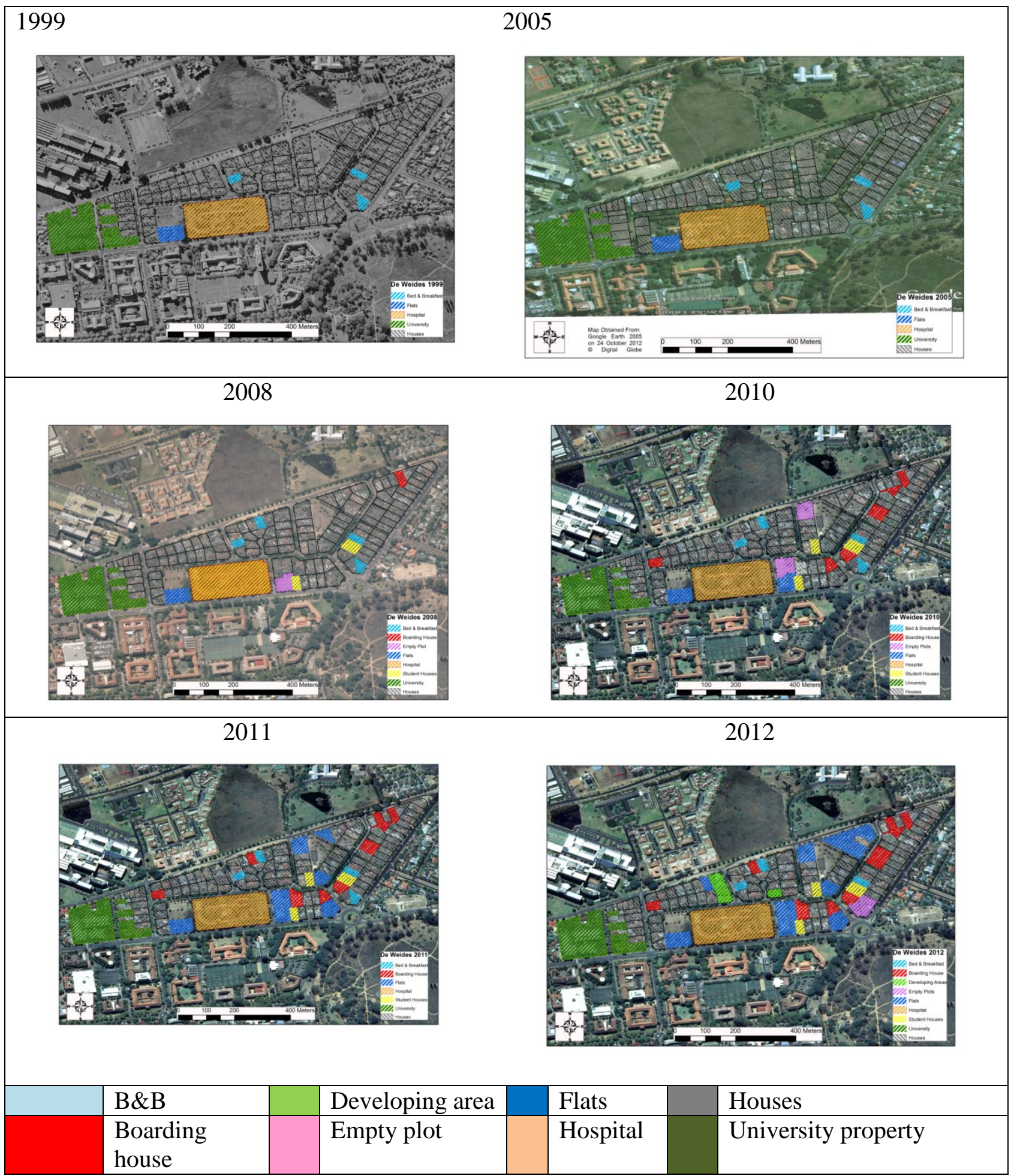

Figure 2: Land use changes in De Weides between 1999 and 2012 (source: Authors and Google Earth)

De Weides was proclaimed and zoned in 1929 as a single residential suburb. In 1979 the zoning was changed to general residential. The new zoning implied that students may have been accommodated, but the owner had to live on the property as well. The zoning type was known as a boarding house (losieshuis). Numerous university lecturers were, at the time, living in this suburb. In the immediate years after the rezoning of the area, houses were monitored on a regular basis by the municipality for compliance. However, as a result of regime changes taking place at local authority level since the 2000s (Seethal, 2004) the local 
authority has failed in this function and a blind-eye approach became the norm; ignoring the growth in student houses in the area. Controlling student houses did not feature as a priority on the political agenda at the time. The spatio-temporal changes in the urban fabric of De Weides are evident in Figure 2. There has been no change in land use between 1999 and 2005. In this period there were one block of flats, three guest houses/B\&Bs and the remaining housing type was residential. It is not possible to account for the number of student houses. Since 2008, however, the urban geography of accommodation in De Weides started changing dramatically. According to Benn (2010) and the Stellenbosch municipality's Integrated Development Plan of 2009, De Weides was earmarked as an area necessary for densification. This allowed for the erecting of multiple flats and boarding houses on properties. An all too familiar scene has been the following: as student houses gradually increase, more and more permanent residents are leaving the suburb. They would either sell their properties directly to a developer or will rent out their houses to students. Over time and with the accumulation of students in the suburb the area falls into decay. Houses and gardens are not maintained. In some cases, the houses bought by developers are left vacant and are vandalised by criminals and homeless people. Such houses are left to the elements of destruction. Because many of these houses are older than 60 years they are protected by the national heritage legislation (i.e. they cannot be demolished or altered).

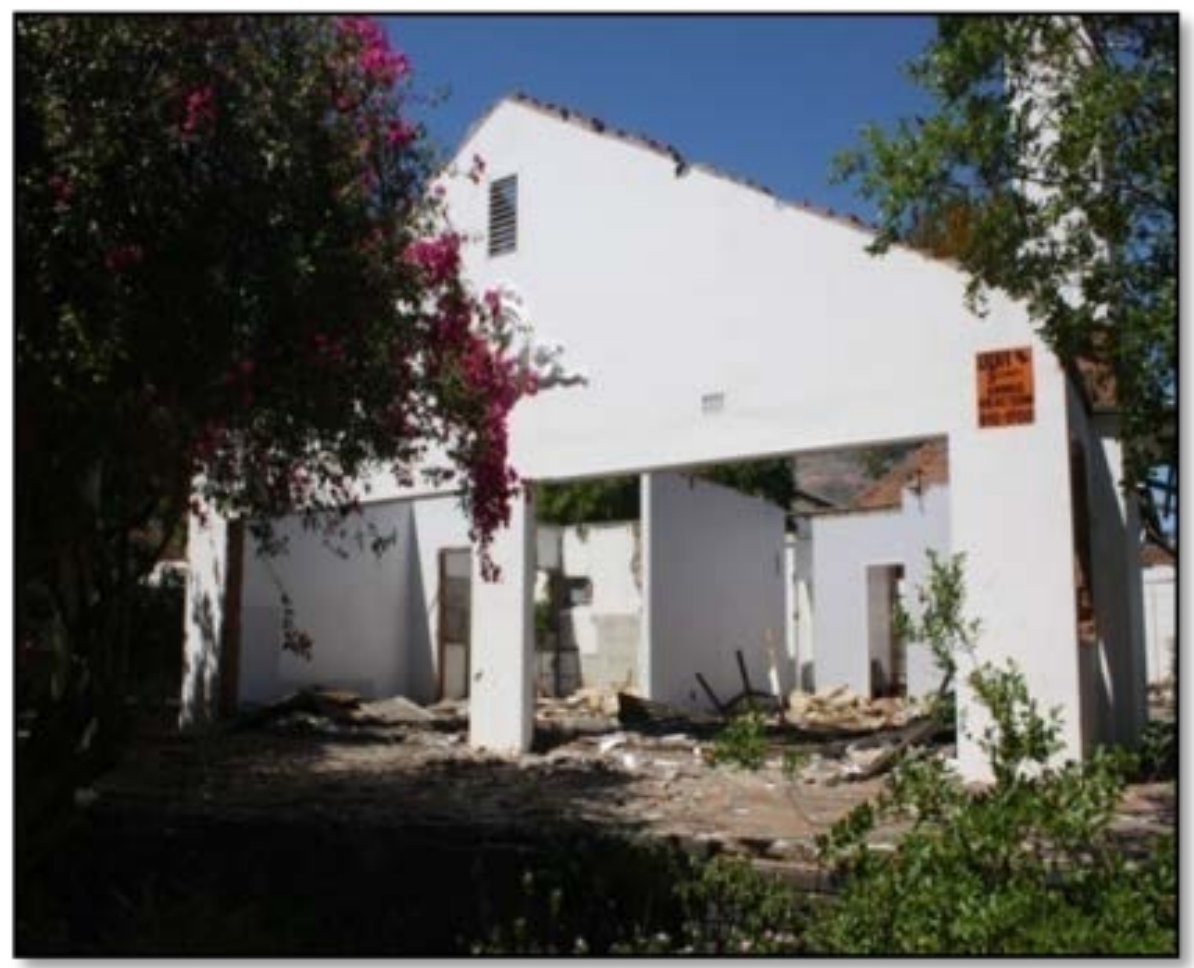

Photo 1: Example of a historic house that has been destroyed by vagrants (source: Authors)

Developers do not want to protect a single house; instead they want to erect a block of flats on the property. As the houses deteriorate further (see Photo 1 as example in De Weides) they submit applications for destruction to the municipality in the context that the original historic house has been destroyed by the elements in any case. In 2009 the municipality has taken the decision to allow for the peripheral areas - outer fringes - of De Weides to be densified and that the inner areas remain single residential: in effect to create a doughnut shape aiming to conserve the historic fabric in the inner area. However, this did not happen as can be seen from Figure 2. In many cases single residential properties are consolidated into a 
bigger property on which flats are developed. These developments are also occurring anywhere in the suburb and not only as was planned for in the periphery of the area. Actual student houses were counted in 2010: there were then already 44 student houses and only 37 permanent residential housing units (guesthouses/B\&Bs included) left in De Weides (Figure 2).

Our survey among student houses revealed that in $51 \%$ of the houses the number of occupants were between 6 and 10 and 22\% were living in houses that accommodated between 11 and 15 students. These are all houses designed for a single family of approximately 4 to 5 persons per household. On average there were for every house, eight vehicles recorded. The monthly rental paid for the houses was sufficient to cover the bond costs of the owners (if they still had a bond to pay off). In terms of not contributing to the social cohesion of a neighbourhood community, $84 \%$ of the student respondents indicated that they "have no clue" who their neighbours are. They also indicated the four main complaints received by permanent non-student residents varied from complaints of noise, having late night parties, parking in the street and the fact that they moan in general about students. Almost half (46\%) of the student houses have been involved in personal quarrels with permanent residents.

The permanent residents that were interviewed have been staying, on average, for 18 years in De Weides. Three-quarters of the respondents have been in conflict situations with students. The four main reasons for conflict creation were noise, public drunkenness, house parties and parking infringements. In order to determine suburb quality of life, respondents were asked to score their suburb on a Likert scale according to various physical, social and economic indicators. An overall suburb satisfaction index of 54 was then calculated. Index values of less than 66 are generally considered very bad. Respondents were asked to indicate whether the presence of students in their suburb has a negative, positive or neutral impact on them in the three categories of social, cultural and economic (Table 1).

Table 1: Positive and negative impacts of students in the suburb

\begin{tabular}{llll}
\hline Social factors & Positive & Negative & None \\
\hline Social interaction with residents & $22 \%$ & $61 \%$ & $17 \%$ \\
Diversity of residents & $52 \%$ & $40 \%$ & $8 \%$ \\
Social cohesion of suburb & $5 \%$ & $87 \%$ & $8 \%$ \\
Social behaviour of students & $8 \%$ & $92 \%$ & $0 \%$ \\
\hline Cultural factors & & & \\
\hline Noisy & $3 \%$ & $97 \%$ & $0 \%$ \\
Student lifestyle & $12 \%$ & $85 \%$ & $3 \%$ \\
Student culture in suburb & $12 \%$ & $85 \%$ & $3 \%$ \\
\hline Economic factors & & & \\
\hline Demand for housing & $67 \%$ & $30 \%$ & $3 \%$ \\
Supply for housing & $70 \%$ & $27 \%$ & $3 \%$ \\
\hline
\end{tabular}

As indicated in the literature, suburbs with a high concentration of students tend to be soft targets for criminals, especially during recess periods. Seventy percent of respondents are of the opinion that the presence of student houses in their area is the main reason for increased incidences of crime. On average the respondents have been victims of break-ins twice.

\section{Bloemfontein}

The purpose of the Bloemfontein Town Planning Scheme of 1954 is to effectively control land use. The scheme makes provision for zoning with regulation and prescribes how and for what a property can be used for. Most properties in Brandwag and Universitas are zoned as single residential 2. This zoning category is defined as a building designed to be occupied by 
a single family with 1 to 1.5 parking spaces for every 4 sleeping rooms. This description evidently does not describe that of a student house, because students are a non-related adult group of people living together on a semi-permanent basis. In the absence of a student housing policy for the city, a policy was formulated in the late 2000s but has as yet has not been implemented. Interviews with planners, employees of the city council, yielded the following: One of the aspects attention was given to was to allow for a special consent use for student houses. In effect this would imply that should the owner sell the property it, thereafter, cannot be used as a student house unless the new owner applies for a special consent use. Instead of a student housing zoning, consent use was proposed, because within the parameters of specified rules and regulations consent use can be taken away should an owner not abide by the rules. The proposed policy also makes provision for security concerns where owners are expected to provide for at least a security fence. Owners must also be able to have proof of making use of garden services to maintain the outside areas of properties. The policy is thus not to contain and restrict the development of student houses, instead emphasis is on better control of land use. A platform will also be created for residents to complain should student houses not stick to the rules.

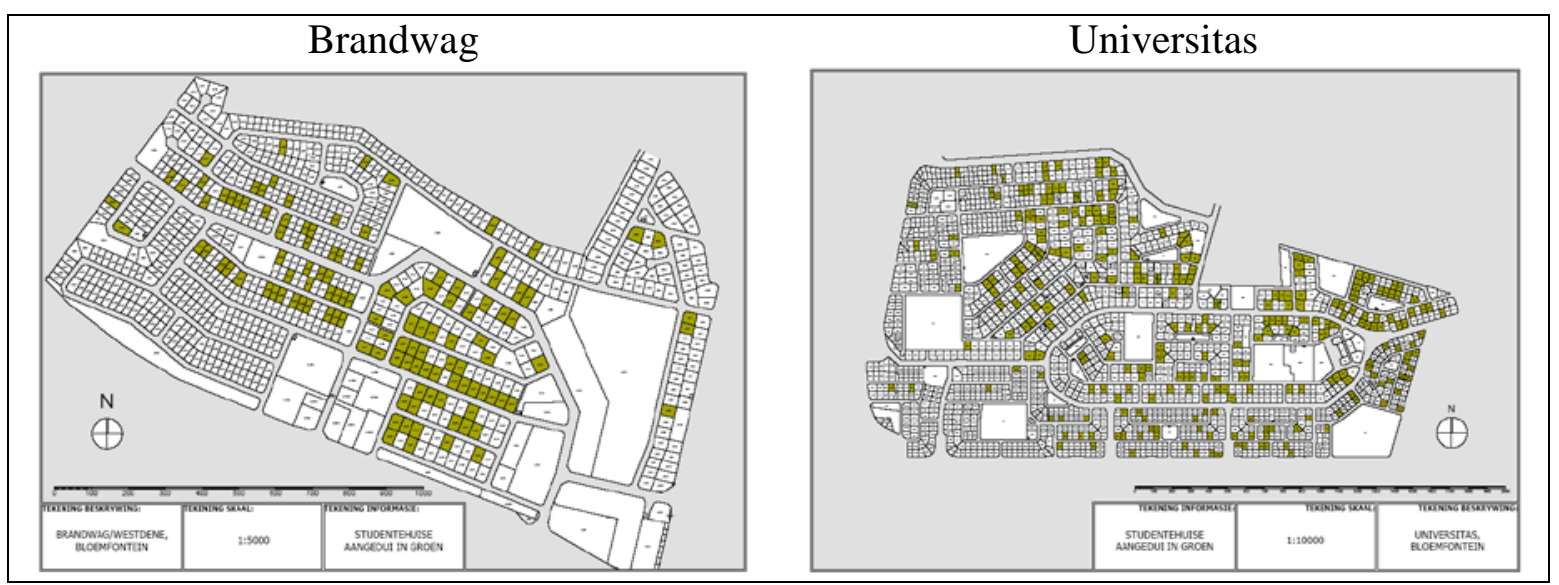

Figure 3: Distribution of student houses in Brandwag and Universitas

In the two case study suburbs of Brandwag and Universitas there are 454 student houses with a total of 1454 students residing there and contributing to approximately one third of the off-campus accommodation of university students. Student houses in Brandwag (with an average of 13 students per house) are slightly more densely populated than Universitas (9 students per house). The spatial location of student houses in the two suburbs are shown in dark shading on Figure 3. There are clearly specific clusters evident in both suburbs suggesting that a process of invasion and succession is taking place. Typically in such conditions a core will develop and from thereon snowballs outwards as original residents adjacent the core start "fleeing"/leaving the area.

Students staying in student houses were asked why they prefer this option of accommodation type. The two main reasons stated were that they do not want to be part of the campus hostel culture and secondly because there is not enough accommodation for them on campus (Figure 4). Transformation at the university is an added dimension to students opting to stay in student houses. Traditionally university hostels have been created on a single-sex basis at both university campuses. However, in student houses it is common for male and female students to live together and conservative neighbours responded that such dissolute behaviour among students are creating socially unacceptable experiences such as sexual practices in the neighbourhood parks (Volksblad, 7 Januarie 2006: 4). Staying in a student house is in most cases also a cheaper option than hostels. A mere $36 \%$ of students in the study 
area are post-graduate students. A handful of cases were observed where a house is only inhabited by post-graduate students and in such cases the average number of residents was very low (6). In addition these houses were also kept very clean and tidy.

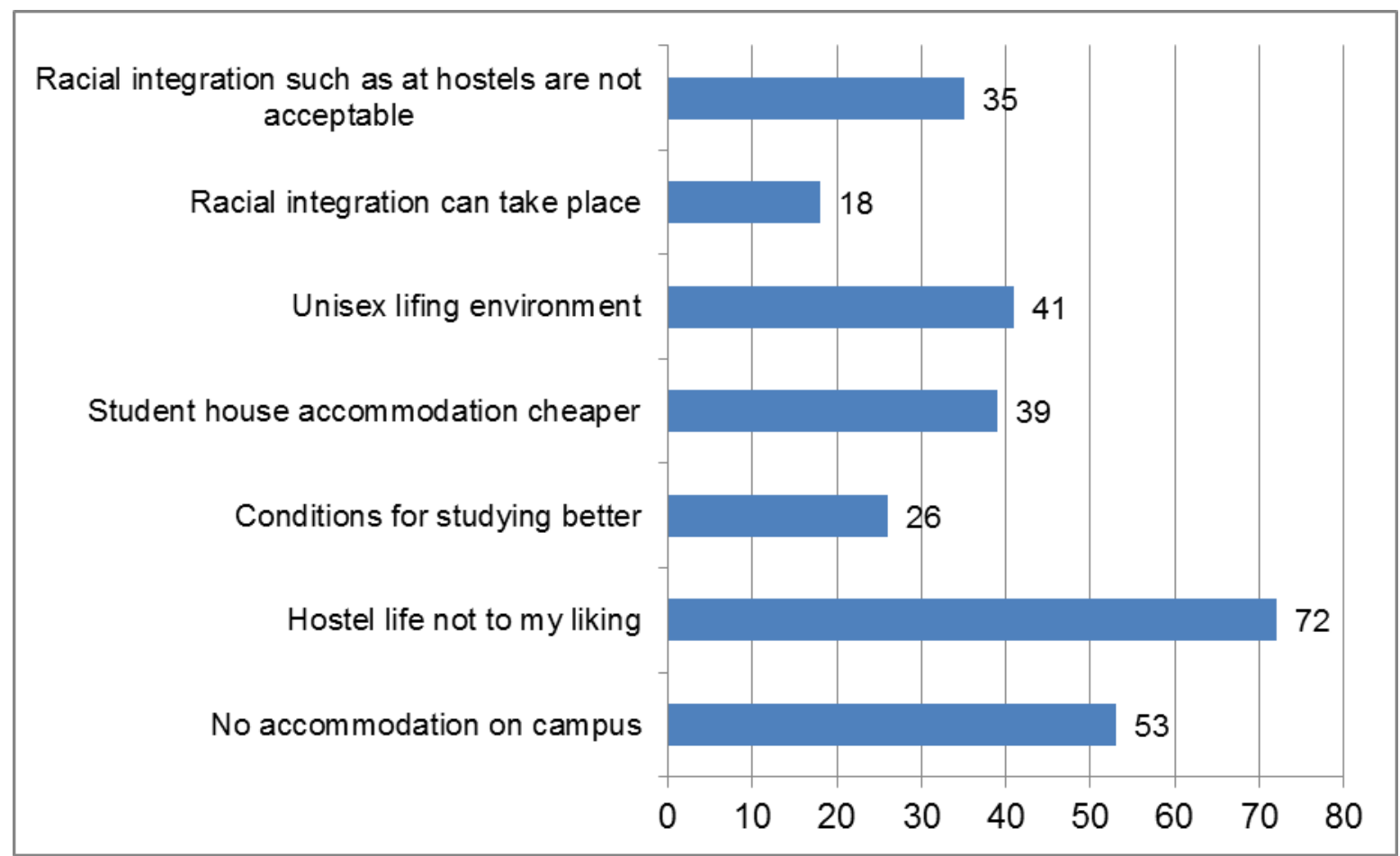

Figure 4: Reasons for wanting to stay in a student house

Unruly behaviour and noise is by far the biggest problem for permanent residents in the suburbs. Just over half the student respondents indicated that they have student house rules but they acknowledge that they do not adhere to these. According to a police superintendent (anonymous interview) cases of "rusverstooring" (disturbing the peace) rarely end up in a criminal case and in some cases, at most, the unruly students will spend a night in jail. As seen in the international literature other criminal activities thrive in areas with clusters of student houses. However, in the two suburbs of Bloemfontein available recorded criminal activity data have seen a decline over a ten year period where between 1998 and 2007 cases declined from 17805 to 14352 .

An anonymous estate agent indicated that the increase in student houses has contributed positively to the property market in both suburbs. The new owners would see the house as an investment that can easily be paid off by students over a couple of years. The demand for student houses, therefore, forced the market to respond and prices increased. The universities are seen as the source market that leads to the creation of this demand. Residents living adjacent to student houses acknowledged that their house prices increased as a consequence of the increase in student houses. However, notwithstanding this positive economic impact, these residents are highly critical of the presence of student houses in their suburb $192 \%$ in Brandwag and $46 \%$ in Universitas said that the image of their suburb has been impacted negatively). Just less than $50 \%$ of residents were also considering relocating elsewhere.

None of the permanent residents were informed about the fact that their neighbouring properties were to become student houses. Those that, however, objected to the metropolitan municipality were only informed that there are currently no regulations in place to prevent or regulate such houses. The university authority is, however, adamant that they are not accountable for any affairs pertaining to the impacts of student houses on the urban fabric in 
the city, outside the boundaries of the university (anonymous interview with university administrator).

At present, neighbours are not aware of the intentions of individuals or developers to establish a student house. The process for lodging complaints against such submissions is also rarely catered for. The application for rezoning encourages public participation. The formulation of a special zoning for student houses and creation of a definition of a student house is in the interest of the public and for broader urban planning fraternity at municipal level. Once a student house is defined, it may empower the authority to do the following: residents and new owners of properties of student houses can formally participate in the process of application for consent uses; the capacity of sufficient services per residential unit can be established beforehand; the impact on the traffic of the surrounding area can be evaluated better; access points to the units such as potentially dangerous entry points can be prevented; controlling sufficiency of parking space (as well as minimizing parking spaces in the backyard of units); and health regulations (hygiene and sanitation) can be better controlled.

\section{Conclusion}

The paper argues that both dramatic percentage increases of student enrolment and resident-based totals directly contributed to a fundamental spatial transformation of suburbs in both cities regarding socio-spatial relations, urban spatial expansion and the resultant spatial impacts as a consequence of these pressures. Neither the university nor the municipalities have kept pace with this influx and alternative urban social-spaces have subsequently been created. One such spatial outcome is studentification. As a consequence of the studentification of urban space, a particular spatial pattern has emerged over the past decades. Negative social, physical and cultural consequences are experienced in the studentified neighbourhoods; resulting in issues such as noise, traffic congestion, high residential density and the loss of the neighbourhood character. There is a lack of social cohesion between the permanent residents and the students and this situation is exploited by property developers. In the process, studentification has inflated the property market, thus excluding low-middle- and middleincome earners from an opportunity to buy property in the town. In the case of Stellenbosch it was seen that, notwithstanding proper zoning, regulated suburbs have experienced dramatic changes to the built and social environment. In Bloemfontein such regulations are called for but it may be too late to pro-actively and sensitively manage studentification.

In terms of policy it would be ideal if all main role-players (such as the university, developers, municipality, homeowners, security agencies) form part of all planning strategies. Policing such a policy can, for example, be dealt with in collaboration with the university's own security arm and the municipal authorities. Sustainable control measures must be implemented to achieve an orderly and legal studentification process. The controls should be restrictive to harmful and illegal studentification practices, but it will not be successful if all parties involved do not benefit and are empowered by the control measures. These measures also have to incorporate all the facets of existing legislation, zoning and policies. Consent use zoning will always create an opportunity for breaking bylaws of tenants and such zoning should not be seen as a solution to managing studentification effectively.

\section{References}

Albrechts, L. (2004) Strategic (spatial) planning re-examined. Environment and Planning: Planning and Design, A31, pp. 743-758.

Allison, J. (2006) Over-educated, over-exuberant and over here? The impact of students on cities. Planning, Practice \& Research, 21(1), pp. 79-94. 
Benn J.D. (2010) Studentifikasie in Stellenbosch. Master's thesis. Stellenbosch, Stellenbosch University, Department of Geography and Environmental Studies.

Bowditch, S. (2001) Good neighbours. Connection: New England's Journal of Higher Education \& Economic Development, 15(3), p. 11.

Chatterton, P. (2000) The cultural role of universities in the community: Revisiting the university-community debate. Environment and Planning, A32, pp. 165-181.

Curtis, P. (2005) Student centres. Guardian. www.guardian.co.uk.

Duke-Williams, O. (2009) The geographies of student migration in the UK. Environment and Planning, A41, pp. 1826-1848.

Griffiths, R.; Bassett, K. \& Smith, I. (1999) Cultural policy and the cultural economy in Bristol. Local Economy, 14 (3), pp. 257-65.

Groenewald, A.C. (1989) Die sosiale lewensomstandighede in Bloemfontein, 1896-1899. Master's thesis. Bloemfontein. University of the Free State.

Hall, F. (2008) Don't blame students for studentification. Guardian. www.guardian.co.uk.

Hubbard, P. (2006). Regulating the social impacts of studentification: A Loughborough case study. Environment and Planning, A40, pp. 323-341.

Kenyon, E. (1997) Seasonal sub-communities: The impact of student households on residential communities. Britain Journal of Sociology, 48(2), pp. 286-300.

Leavey, K. (2004) Communities and colleges: Utilizing public relations techniques and strategies to solve chronic town-gown problems. Rowan: Rowan University.

Lees, L. (2008) New-build gentrification: Forms, places, processes. Population, Space and Place, (11), pp. 251-268.

Macintyre, C. (2003) New models of student housing and their impact on local communities. Journal of Higher Education Policy and Management, 25(2), pp. 109-118.

Midgley, C. (2002) Hell of residence. Times Online. www.timesonline.co.uk.

Munro, M.; Turok, I. \& Livingston, M. (2009) Students in cities: A preliminary analysis of their patterns and effects. Environment and Planning, A41, pp.1805-1825.

Potgieter, P.J. (2005) Studentehuise rondom die Universiteit van die Vrystaat. Stads- en Streekbeplanning, 48, pp 17-25.

Rey, J. (2007) Off-campus apartments booming: Focus: Student housing. Buffalo News, The (NY). http://www.buffalonews.com.

Rugg, J.; Rhodes, D. \& Jones, A. (2000) The nature and impact of student demand on housing markets. Layerthorpe: Joseph Rowntree Foundation.

Russo, A.; Van den Berg, L. \& Lavanga, M. (2007) Toward a sustainable relationship between city and university. Journal of Planning Education and Research, 27(2), pp. 199216.

Sabri, S. \& Ludin, A.N. (2009) 'Studentification': Is it a key factor within the residential decision-making process in Kuala Lumpur? Available at: http://www.fab.utm.my/download/ConferenceSeminar/SEATUC200904P.pdf

Seethal, C. (2004) Postmodern urban politics in South Africa: the case of Stellenbosch (20002004). Paper presented at the Centennial Convention of the Association of American Geographers, March, Philadelphia, USA.

Slater, T.; Curran, W. \& Lees, L. (2004) Guest editorial, Environment and Planning, B36, pp. 1141-1150.

Smith, D. (2007) The politics of studentification and '(un)balanced' urban populations in the United Kingdom: an update. Brighton: University of Brighton.

Smith, D. \& Holt, L. (2007) Studentification and 'apprentice' gentrifiers within Britain's provincial towns and cities: Extending the meaning of gentrification. Environment and Planning, A39, pp.142-161. 
Smith, N. (1987) Of yuppies and housing: gentrification, social restructuring, and the urban dream, Environment and Planning D: Society and Space, 5, pp. $151-172$

Standing Conference of Principals (SCOP) \& the Local Government Association. (2006) Studentification: A guide to opportunities, challenges and practice. Available online: http://www.universitiesuk.ac.uk/highereducation/Documents/2006/StudentificationGuide. pdf

Stefanovska, J. \& Koželj, J. (2012) Urban planning and transitional development issues: The case of Skopje, Macedoni.. Urbani Izziv, 23(1), pp. 91-100

Volksblad. 2006. Ontstoke Brandwag-inwoners vergader. 7 Januarie, p. 4.

Wojtas, O. (2003) We don’t want students on our doorstep. Times Higher Education Supplement, 1607, p.13.

Wynne, D. \& O’Connor, J. (1998) Consumption and the postmodern city. Urban Studies, 35, pp. 841-64.

www.communities.gov.uk. (2008) New report tackles neighbourhood studentification problem

Available online: www.communities.gov.uk.

Zhang, J; Kotze, N \& Minghui, YU. (2012) Living in a changing Chinese urban landscape: The Dalian case study. Urbani Izziv, 23(2), pp 93-102. 